\title{
Climate Change Adaptation Strategies in Agriculture: Cases from Southeast Asia
}

\author{
Rajendra Prasad Shrestha ${ }^{1}$, Nani Raut ${ }^{2}$, Lwin Maung Maung $\mathrm{Swe}^{3} \&$ Thida Tieng ${ }^{1}$ \\ ${ }^{1}$ School of Environment, Resources and Development (SERD), Asian Institute of Technology (AIT), Thailand \\ ${ }^{2}$ Dept. of Environmental Science and Engineering, Kathmandu University, Nepal \\ ${ }^{3}$ Ecosystem and Economic Development Group, Myanmar \\ Correspondence: Rajendra Prasad Shrestha, Asian Institute of Technology, Thailand, Tel: 66-851352634, E-mail: \\ rajendra.shrestha@gmail.com; Nani Raut, Dept. of Environmental Science and Engineering, Kathmandu \\ University (KU), Nepal. Tel: 977-981-834-9489. E-mail: rautnani7@gmail.com
}

\author{
Received: February 23, 2018 Accepted: April 16, 2018 Online Published: May 8, 2018 \\ doi:10.5539/sar.v7n3p39 URL: https://doi.org/10.5539/sar.v7n3p39
}

\begin{abstract}
Climate change has become apparent and been threatening more and more in Southeast Asia. Its impacts on agriculture and adaptation strategies at household level in farming systems areas are explored. The study focused on better understanding of climate change impacts and adaptation practices in four villages of Myanmar and Cambodia. Household questionnaire survey, focus group discussions and key informant interviews were used for data collection at household and community level supplemented with secondary data. Dry Zone farmers of Myanmar reported increase in crop diversity while in the Kampong Speu province in Cambodia, the number of rice growing farmers increased together with cultivation of other crops, such as cassava, palm fruit, sugarcane, mangoes, watermelons and vegetables. Farmers changed their cultivation practices as adaptation strategies in various ways: change in cropping calendar, crop varieties, machinery for cultivation practice, and change in area for cultivation. The shift in cropping calendar has occurred from two weeks to one month. Diverse strategies were reported in adapting to water scarcity in agriculture, such as system of rice intensification and water pumping. Farmers also adopted strategies for coping with declining soil productivity. These include animal manure application, compost making and application, crop rotation and crop residues retention. In particular, Dry Zone farmers prefer to apply animal manure rather than other practices because of its vast benefits, such as buffering capacity, effectiveness for plant growth and cheaper price. Cooperative actions are becoming increasingly needed when an individual could not afford adaptation strategies. However, barriers to adaptation strategies are to be reduced to promote climate adaptive practices in agriculture.
\end{abstract}

Keywords: Myanmar, Cambodia, crop calendar, water stress, adaptation strategies

\section{Introduction}

The Intergovernmental Panel on Climate Change (IPCC) assessment report revealed that adverse impacts of climate change are expected to affect agricultural sector in Southeast Asia mainly due to increase in occurrence of droughts, increase in the occurrence of intense rains, and rise in temperature. The occurrence of droughts will result in crop failure in areas with rain-fed cultivation, while occurrence of intense rains will result in decline in crop yield from crop damages (MoNREC, 2016).

Agriculture sector is the backbone of economy for both Myanmar (FAO, 2018) and Cambodia (Jalilian et al., 2010). In Myanmar, agriculture sector contributes 34\% (2008-2009) of GDP, employs $61 \%$ of the labor force and $70 \%$ of the population reside in rural areas and are mainly engaged in agriculture, livestock and fishery for their livelihood (DAP, 2010). Likewise, as confirmed by MEF (2010), agriculture continues to have a central place in rural livelihood, accounting at least a third of GDP of Cambodia. Agriculture in Cambodia is strongly correlated with rain-fed system; therefore any variation in climate will have impact on agricultural productivity and eventually economics of the country as a whole. Moreover, climate change has become apparent and been threatening more and more in the region (UNDP \& MoE, 2001).

In Myanmar, a general warming trend of mean annual temperature and with decreasing trend of precipitation within the range of 2 to $339 \mathrm{~mm}$ have been reported across the country (NCEA, 2010a). The abnormal synoptic 
situations of climate in recent years, has changed rainfall pattern of Myanmar from bimodal distribution to unimodal distribution. In that case, duration of rainy season was significantly reduced to 105 days from 145 days of normal distribution, with later onset of monsoon, lack of dry spell period in July and earlier withdrawal of monsoon. This may lead to implications for agricultural sector as $48 \%$ rice cultivation is in the favorable rain-fed lowland (Swe et al., 2014). In terms of climatic stressors, and adverse impacts, the Central Dry Zone is one of the most impacted regions in Myanmar (MoNREC, 2016) because disappearance of dry spell period in July delays crop harvesting or causes the crops yield to decline (NCEA, 2010b; Lwin, 2010). Similarly, Cambodia experienced a prolonged dry season, followed by a month of heavy rains resulting in flash floods that destroyed crops. It is predicted that the temperature increase would be high $\left(0.036^{\circ} \mathrm{C}\right.$ per year) in low-altitude areas such as central Cambodia and the northeast; and lower $\left(0.013^{\circ} \mathrm{C}\right.$ per year) in high-altitude areas such as the south-west (UNDP, 2011). Drought and soil fertility depletion are among the most important factors limiting crop production in Cambodia (Touch et al., 2016b).

Adaptation to climate change is considered key in combating climate change in addition to mitigation measures throughout the world. Adaptation, a complex, multidimensional, and multi-scale process, has been defined as adjustments to behavior or economic structures that reduce vulnerability of society in the face of scarcity or threatening environmental change (Adger et al., 2003; Bryan \& Behrman, 2013). The adaptation responses have been classified according to the scale at which they occur; intent; timing with respect to the climate stress; duration; form/type; and effect (Bryant et al., 2000; Smit \& Skinner 2002; Agrawal \& Perrin 2008; Heltberg et al., 2009). The Intergovernmental Panel on Climate Change (IPCC, 2007, 2012) distinguishes between planned adaptation, which results from deliberate interventions; and autonomous adaptation, which is spontaneous, acts of reducing risks. However, study also argued on the autonomous adaptation as it might not occur spontaneously, rather it depends on how changes impact the livelihood of people (Ayers, 2011). As adaptation to climate change impacts is the major development agenda in many developing countries, it is very crucial to have really applicable practices in the field. The recently formulated Climate Smart Agriculture Strategy (MoNREC, 2016) in Myanmar emphasizes on adaptive measures, such as crop varieties, farming practices, disaster-risk management, and crop loss risk management. Likewise, several agricultural technologies and practices based on water and land management (such as system of rice intensification, climate resilient farming etc.) that fit with principles of climate resilient agricultural development are being tested, developed and promoted in Cambodia (UNDP, 2011). Traditional knowledge can provide efficient, appropriate and time-tested ways of advising and enabling adaptation to climate change in communities, locally adapted practices have to be regarded as the starting point in developing new strategies for adaptation to have really applicable practices in the field (UNFCCC, 2007).

Adapting agricultural systems to climate change is urgent because its impact on agriculture is already evident and the trends will continue even if emissions of GHGs are stabilized at current levels whereas adaptation can substantially reduce the adverse economic impact (Bank, 2006). Despite a lot of adaptation options currently being applied, more adaptation options than that of current level are required to reduce upcoming impacts (UNFCCC, 2007). The impacts of climate change on smallholder farms will be locally specific and difficult to quantify due to variations and complexity of farming systems and farmers' livelihood. The issue of understanding climate change impacts at farm level can be enhanced by documenting local knowledge, attitudes and practices (Tiyo et al., 2015; Debela et al., 2015). It is not well documented at local level what and how adaptation is practiced. Therefore, this paper aims to 1) study farmers' perception on trends, causes and impacts of climate change; 2 ) assess adaptation strategies in cultivation practices to climate change impacts in Dry zone and rain-fed areas; and 3) analyze factors influencing household adaptation decisions.

\section{Research Methodology}

\subsection{Study Area}

The study was conducted in Shwe Twin village of Nyaung Oo township and Takama village of Kyaukpadaung township of Central Dry Zone region in Myanmar; and Kork and Tropang Andong villages of Kampong Speu province, which is one of the 24 provinces of Cambodia (Figure 1). There were a total of 124, 100, 115 and 105 households in Shwe Twin, Takama (in Central Dry Zone area), Tropang Andong and Kork (in Kampong Speu province) villages respectively. The selected study areas in both countries have similarities in terms of frequent and prolonged drought and poor and delayed rainfall. Further, agriculture is the major livelihood activity of both study areas.

Dry Zone covers approximately 35\% of Myanmar's cultivable land. The annual rainfall is about $600 \mathrm{~mm}$ to 1400 $\mathrm{mm}$. The crops that are grown in the study area are sesame, groundnut, sunflower, rice, millet, cotton and 
tobacco (DMO \& FD, 2009). Kork village is located in Sangke Satop Commune of Aoral Disctrict and Tropang Andong is located in Nitean Commune of Basedth District in Cambodia. Rice is the dominant crop in the study sites together with the production of other crops such as cassava, palm fruit, sugarcane, mangoes, watermelons and a number of vegetable crops (USAID, 2008).

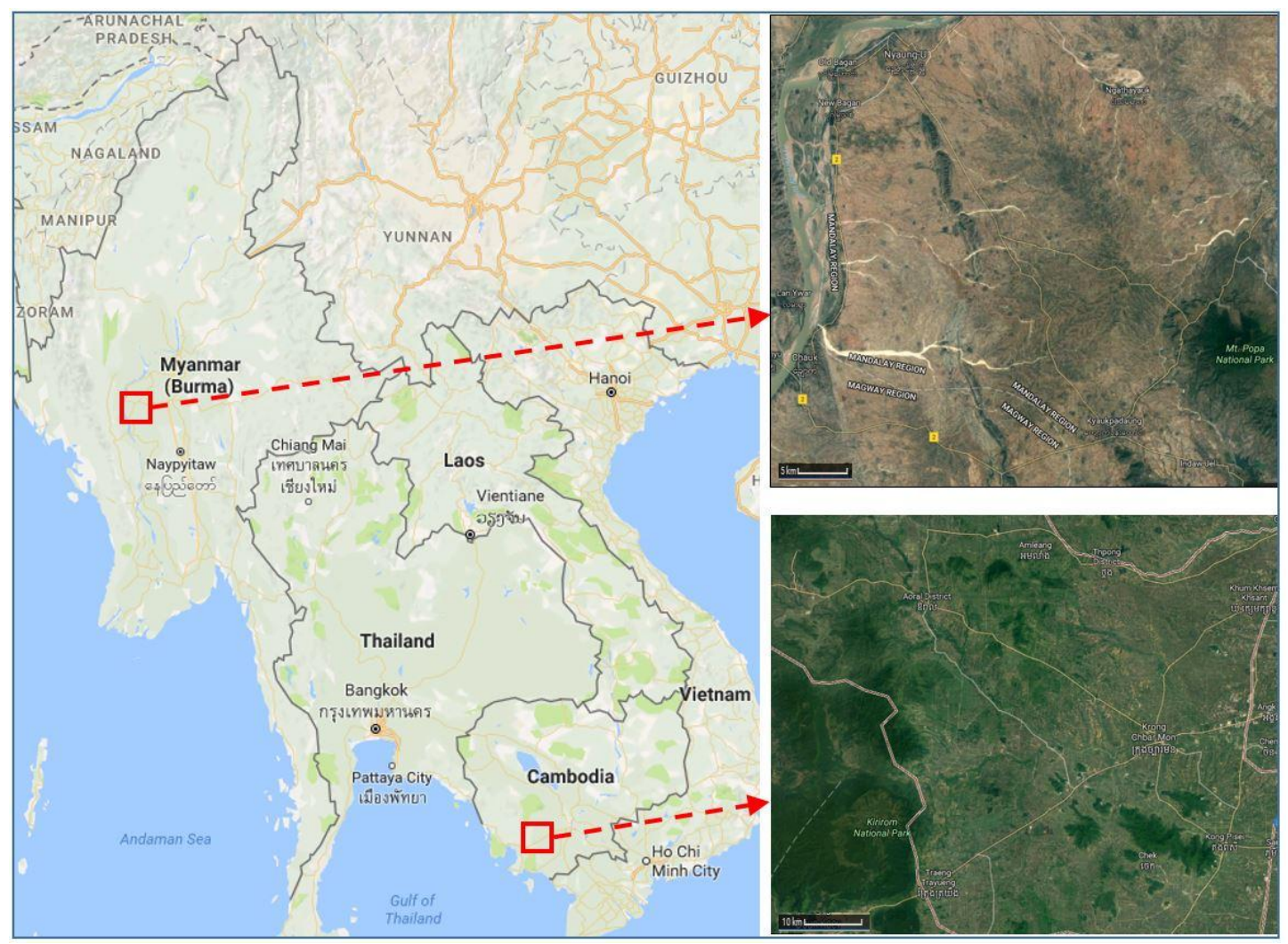

Figure 1. Location of the study area

\subsection{Data Collection}

Both qualitative and quantitative approaches were applied in this study. Different data collection methods were used to collect primary and secondary data in this study.

\subsubsection{Secondary Data Collection}

Climatic parameter, such as rainfall data and monthly maximum and minimum temperature data were collected from village head, provincial department for DRR and government ministries, such as DMH (Department of Meteorology and Hydrology), MAS (Myanmar Agricultural Services) and the Ministry of Water Resource and Meteorology. In addition, secondary data of historical climate change events, such as drought, excessive rainfall, heat and cold waves, and its impacts on rural livelihoods, agriculture related land use maps of study areas, soil fertility status, crop yields, irrigation systems, and government policies on climate change were reviewed from the reports of various organizations, namely MOECF (Ministry of Environmental Conservation and Forestry) and MOAI (Ministry of Agriculture and Irrigation); EcoDev (Ecosystem Development Group) NCEA (National Commission for Environmental Affairs), provincial department for DRR (Disaster Risk Reduction) and provincial department of environment besides other sources of published literature.

\subsubsection{Primary Data Collection}

Household questionnaire survey, focus group discussion and key informants interview were used as primary data collecting methods. A structured questionnaire comprising both close and open ended questions were used at household level. Random sampling was used for household survey and a minimum of $30 \%$ households was selected to represent the total population in each area. However, based on availability of respondents and their willingness to participate in survey, number of surveyed households increased. Thus, a total of $39(31 \%), 67$ (67\%), 35 (30\%) and 34 (32\%) households were selected from Shwe Twin, Takama (in Central Dry Zone area, Myanmar), Tropang Andong and Kork (in Kampong Speu province, Cambodia) villages respectively. Heads of 
the sample households were interviewed using the questionnaire. The data collection was mainly focused on perception of farmers to climatic trends, causes and impacts of climate change and their adaptations to climate change.

Focus group discussions were held in order to reaffirm individual perceptions collected from household questionnaire survey and to do in-depth survey especially for qualitative outputs concerned with farmers' perception to climate change and their behaviors responding to climate change events by asking the questions from a checklist. One focus group discussion in each village was conducted. The group consisted of 10 to 15 participants of both male and female with age above 60 years. The reason behind selecting elderly people was to get the age experienced perceptions regarding changes in climate and cropping pattern.

In addition, key informants i.e. key farmers, NGO staff, irrigation officers, people involved in DRR and agricultural extension workers were interviewed in order to carry out an in-depth survey about history and current climate change events, farmers' responses and government and NGOs activities in responding to climate change in the study areas by using checklist.

\subsection{Data Analysis}

The data were analyzed using SPSS (version 19.0). Mann-Kendall's test was used in order to perform trend analysis for rainfall and temperature data which could subsequently compare the farmers' individual perception about rainfall as well as temperature trend. In this case, 30 years monthly rainfall data and monthly rainy days from all study sites were used for rainfall trend analysis.

Qualitative analysis of information from household survey, focus group discussions and key informant interviews was used throughout the study. Descriptive statistics were used to analyze the quantitative data and were presented in percentages in figures and tables. One-Way ANOVA (Analysis of variance) was used in order to identify the differences between three different series groups i.e. current, past 5 years and past 10 years regarding agronomic practices and inputs used in agricultural production.

A weighted average index (WAI) was also applied, as shown in the following equation, in order to analyze farmers' perception to causes and impacts of climate change and respondents' satisfactory level of current coping strategies, respondents' perception for the responsibility and their willingness to take part in climate change adaptation activities. Previous studies have also applied the weighted average index (WAI) to assess farmers' perceived important adaptation strategies to climate change (Ndamani \& Watanabe, 2015; Devkota et al., 2014)

$$
\mathrm{WAI}=\frac{\mathrm{F} 1(1)+\mathrm{F} 2(0.8)+\mathrm{F} 3(0.6)+\mathrm{F} 4(0.4)+\mathrm{F} 5(0.2)}{\mathrm{N}}
$$

Where, WAI $=$ Weighted Average Index, F1 = Frequency responding for the $1^{\text {st }}$ rank, F2 $=$ Frequency responding for the $2^{\text {nd }}$ rank, F3 $=$ Frequency responding for the $3^{\text {rd }}$ rank, F4 $=$ Frequency responding for the $4^{\text {th }}$ rank, F5 $=$ Frequency responding for the $5^{\text {th }}$ rank, $\mathrm{N}=$ Total number of responses

\section{Results and Discussion}

\subsection{Perception of Farmers on Determinant Climatic Factors}

Farmers, who were interviewed, reported that rainfall and temperature might have determinant effect on agriculture. In Kork and Tropang Andong villages in Cambodia, majority of the farmers (62\%) responded that they received less amount of rain compared to last thirty years. However, the Mann-Kendall's test showed no significant trend in the rainfall pattern since last thirty years (Figure 2). Nevertheless, in the year 2000, the province received the highest rainfall in the whole country. There was significant flood for three consecutive years during 2000 to 2002 (UNDP, 2011). Majority of the respondents (68\%) mentioned that the average temperature for both dry and rainy season was increasing. However, there was no statistically significant increase in temperature. In Shwe Twin, Takama villages in Central Dry Zone area, majority of the respondents (91\%) perceived unusual trend of rainfall (table 1) and $80 \%$ of the farmer perceived unusual length of dry spell period. Half of the respondent farmers perceived early onset of the rainy season, while $31 \%$ had seen it as a usual trend. However, the annual rainfall data did not show significant trend (Figure 3). While it shows significant trend for annual raining days in both study areas. This means the regular amount of rainfall was distributed in more than usual number of days in last 30 years. In this case, farmers' perception on unusual length of dry spell period could not be well validated by recorded rainfall data. Both farmers' perception and climatic data revealed the same trend of increasing temperature in Central Dry Zone although statistically not significant. The graphs resulted from the climatic data highlight that the maximum temperature in Dry Zone area is under increasing trend while minimum temperature is unchanged in last 30 years. 
Farmers perceived increasing temperature and decreasing rainfall trends, which is also explained by the recorded data although not statistically significant. The results are in consistent with other studies in Southeast Asia by McSweeney et al., 2012; Touch et al., 2015; and Touch et al., 2016a. Farmers are often able to perceive the climate change reasonably correctly (Le Dang et al., 2014; Touch et al., 2016a).

Table 1. Farmers' perception on rainfall trend

\begin{tabular}{lll}
\hline \multirow{2}{*}{ Trend } & \multicolumn{2}{l}{ Percentage of Respondents } \\
\cline { 2 - 3 } & Cambodia & Myanmar \\
\hline Increasing & 23 & 40 \\
Decreasing & 62 & 51 \\
Usual & 15 & 9 \\
\hline
\end{tabular}

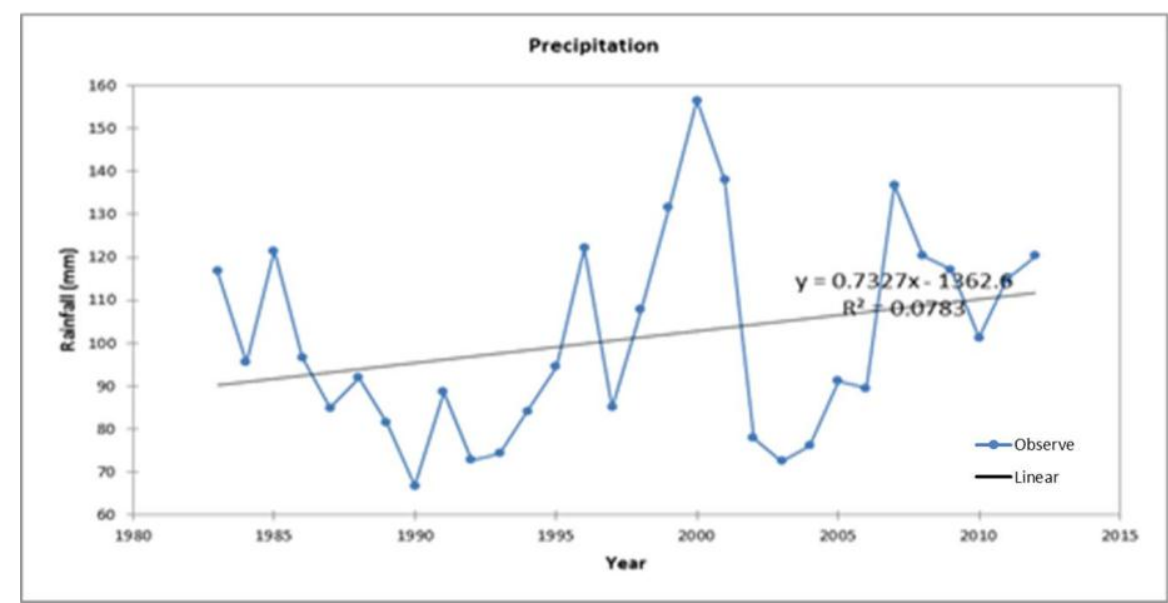

Figure 2. Annual Rainfall of Kampong Speu Province of Cambodia in last 30 years (1983-2012)

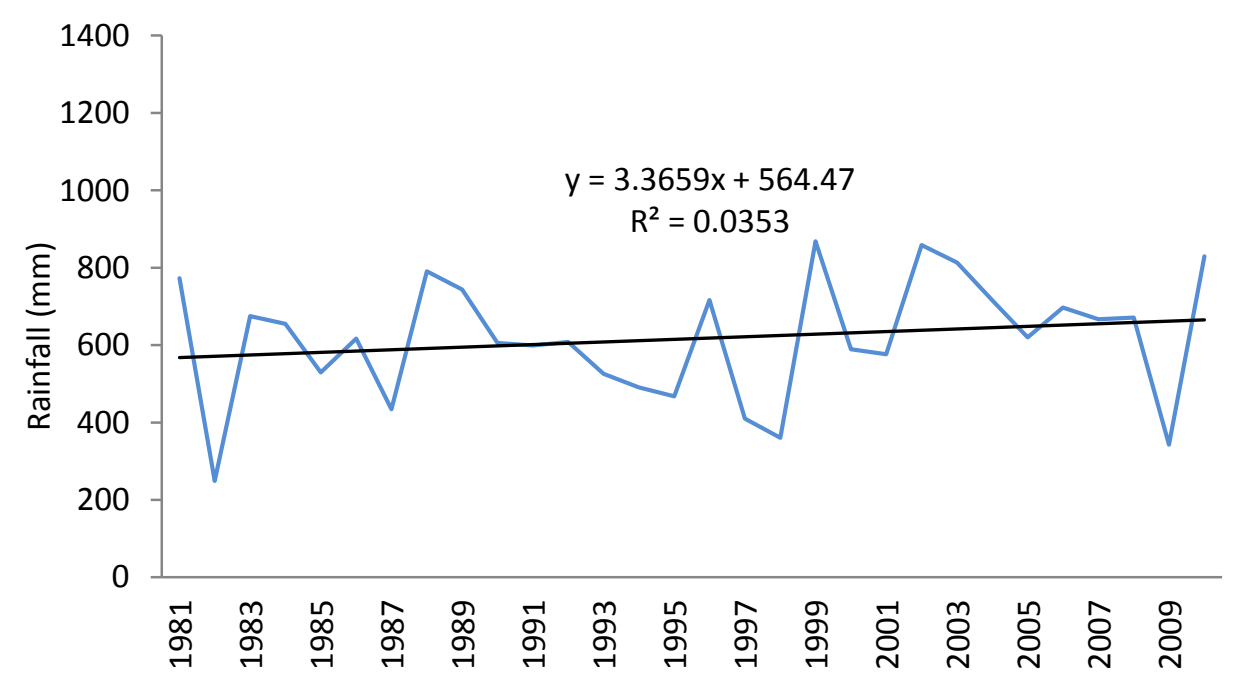




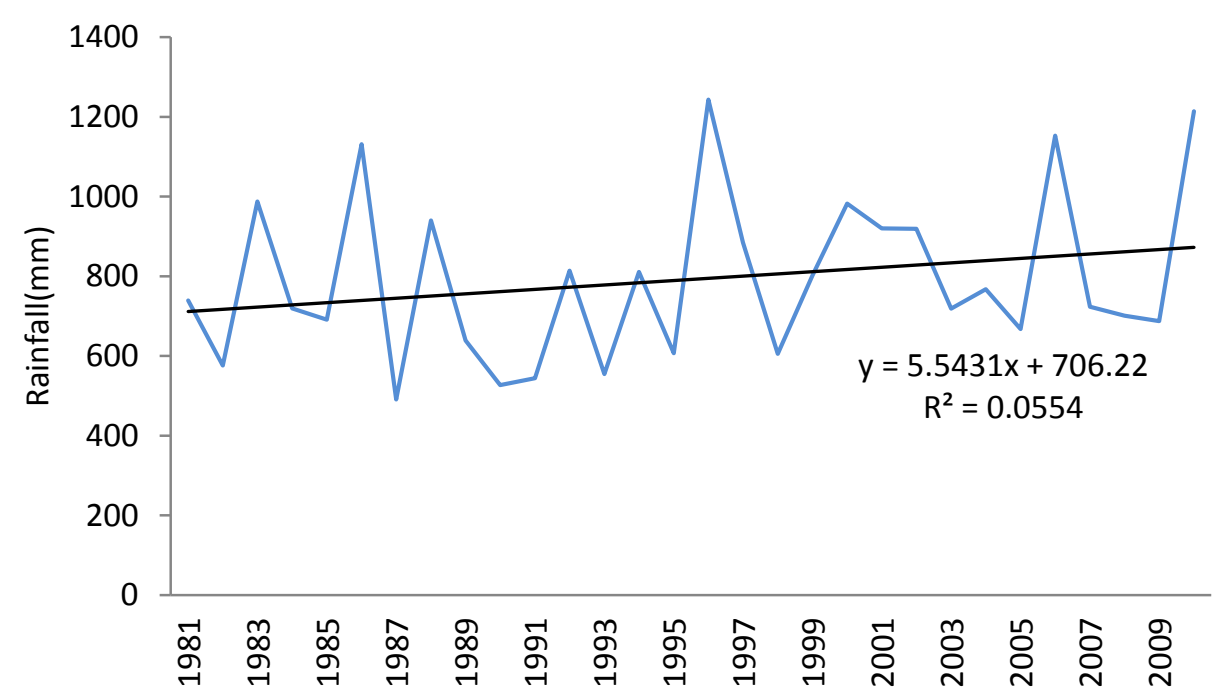

Figure 3. Annual Rainfall of Kyaukpadaung Township \& Nyaung Oo Township in Myanmar in last 30 years (1981-2010)

\subsection{Farmers' Adaptation in Cultivation Practices to Climate Change Impacts}

\subsubsection{Change in Crops Grown}

Rice is the dominant crop for the Kampong Speu province. Majority farmers (70\% respondents) were growing rice in their land. Farmers also have grown some other crop such as cassava, palm fruit, sugarcane, mangoes, watermelons and variety of vegetables. The increase in the number of rice growing farmers compared to last thirty years was because they have either shifted from other crops to rice or they started rice cultivation in fallow land in order to increase their income.

Dry Zone farmers are adopting diverse crops compared to 10 years ago. More than $40 \%$ of respondents perceived that crop diversity is increasing. In fact, all crops except rice were grown since more than a decade, whereas rice cultivation was started after 2006 (Figure 4). Likewise, sesame-growing area was considerably shrunk as its cultivation was significantly decreased over the period of 10 years especially due to decreasing early monsoon rainfall, as sesame is an early monsoon crop. The sesame cultivation area was also occupied by pigeon pea and groundnut as the farmers found multiple benefits in terms of animal feed and firewood without having much labor investment whereas high profit is the major motivation for growing groundnut.

The crop types in Cambodia and Myanmar are different as the crops depend on local climate. Rice is the dominant crop together with cassava, fruit trees and vegetables with less crop diversity in Kampong Speu province. This finding was in line with other study in Cambodia, which also reported decline in crop diversity with cassava had become predominant crop with fruit trees (Touch et al., 2016a). In contrast to Cambodia, crop diversity was higher in Dry Zone region. In both countries, farmers reduced the cultivation of some crops because profitability had declined over few years due to yield decline and occasional crop failures. The similar trend of profit making by adopting new crops and vegetables was also observed by Raut et al. (2011) and Dahal et al. (2009) in hills of Nepal. This contradicts the decision to intensify crop production was motivated by the wish to maximize food for own consumption, rather than the profit factor (Ellis, 1989). However, more active adaptation is driven by farm characteristics and socio-economic condition, such as farm income, farm size (Habiba et al., 2012; Alauddin \& Sarker, 2014). 


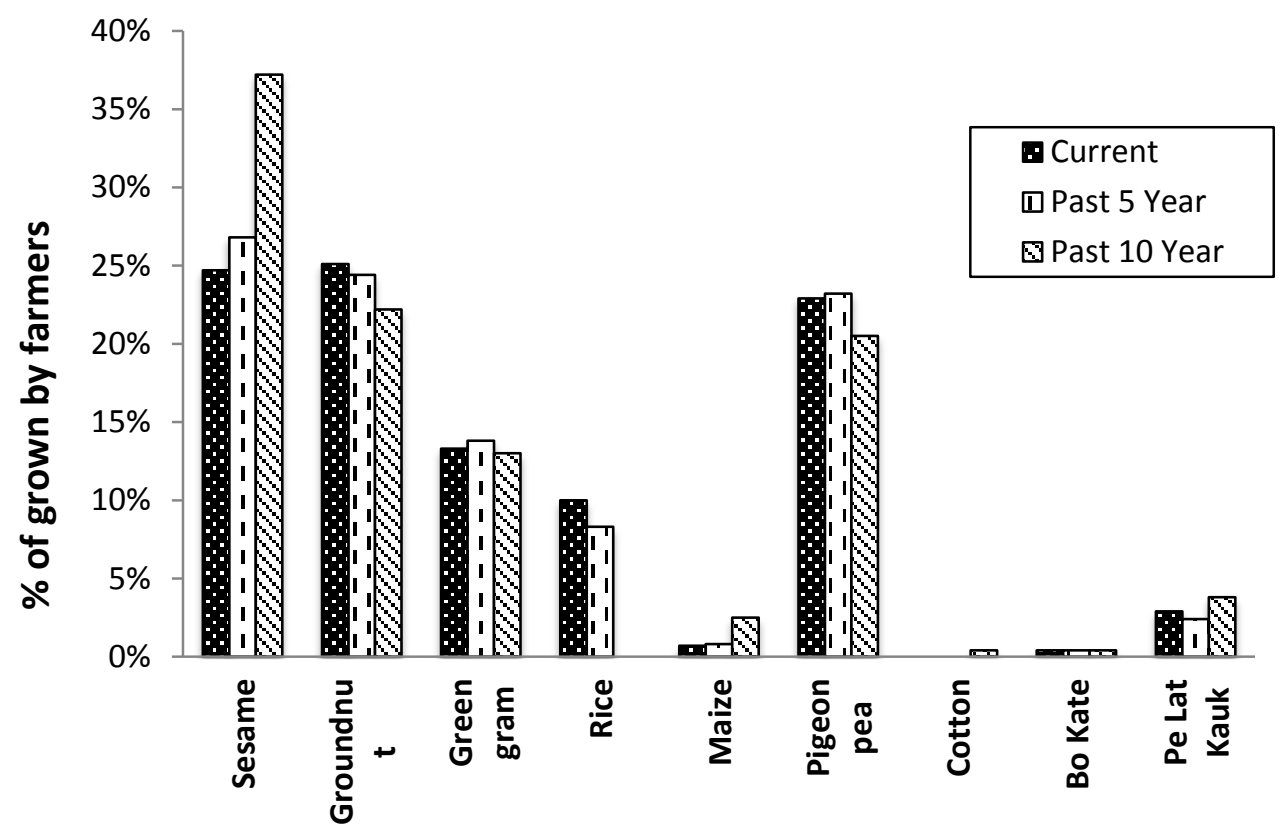

Figure 4. Crop diversity trend in Dry Zone in Myanmar in last 10 years

\subsubsection{Shift in Cropping Calendar}

Majority of respondents (72\%) of Kampong Speu province explained their adaptation in agriculture. Farmers have changed their cultivation practices in various ways: change in cropping calendar; crop varieties; machinery for cultivation practice and change in area for cultivation as indicated in figure 5. Majority of farmers have shifted their cropping calendar. In the past, farmers used to start rice seeding in May, while at present rice seeding is done late in June (Figure 6). Farmers (37\% of respondents) started growing new crop varieties that are suitable with present climate. Few (3\%) farmers have changed the cultivation and agronomic practices, such as increased or decreased amount of fertilizer and pesticide, mixed cropping and minimum tillage. Cropping calendar in Dry Zone area usually covers eight months with the onset of early monsoon rain during third or fourth week of April. However, from the survey and discussions with the farmers, it was recorded that the crop calendar has shifted further by two weeks starting from early May instead and harvesting in late December for sesame and pigeon pea cultivation in Shwe Twin village due to late onset of monsoon rain (Figure 6). No shift in cultivation was reported for Takama village.

Different adaptation strategies have recently been initiated to combat the adverse impacts of climate change at national as well as the local levels. In this study, the shift in crop calendar has occurred by two weeks to one month in both study countries. In other Southeast Asian countries also, adjustment on cropping calendar has been observed particularly on planting and harvesting time based on the start of rainy season (Arunrat et al., 2017). In some areas, communities are responding autonomously to climate change stresses (Tiwari et al., 2014). As a coping mechanism in agricultural production, farmers are shifting their agricultural calendars. They have changed the timing of sowing seeds and timing of plantation, as well as adopted early ripening and drought tolerant varieties in their farmlands (Paudel et al., 2014; Tiwari et al., 2014). Study showed that the timing of plantation, number of planting and harvesting in a year however, substantially depends on both economic and climate conditions (Kotera et al., 2014), although weather induced limitation on workability is a key factor. The delay of some farm operations could lead to crop failure (Sawano et al., 2008). Nonetheless, studies showed adaptation practices were location specific and affected the socioeconomic condition (Hinkel, 2011; Vincent, 2007). 


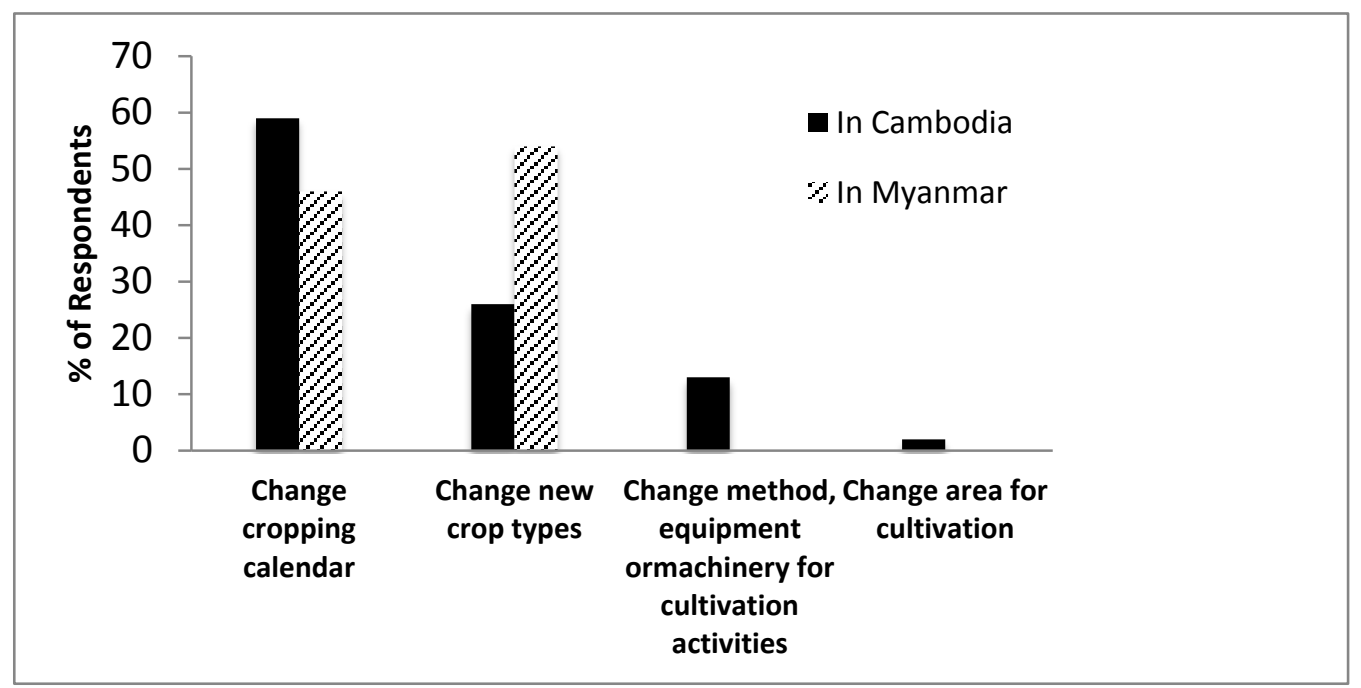

Figure 5. Percentage of Respondents who have changed their cultivation practice due to change in climate

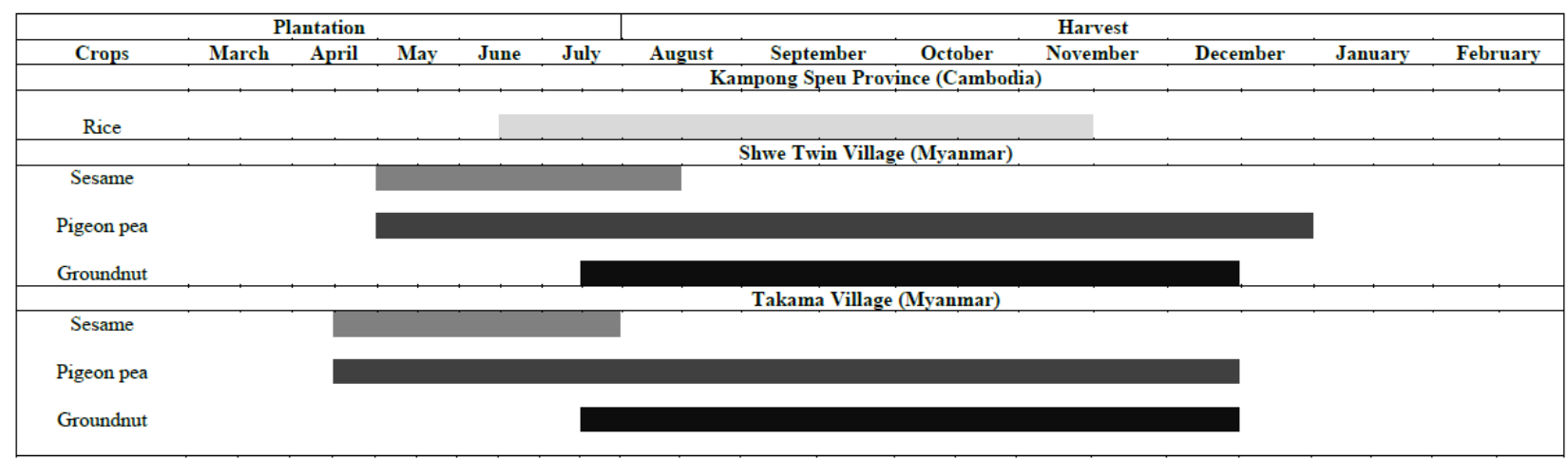

Figure 6. Current cropping calendar in study sites

\subsubsection{Adaptive Measures to Cope with Water Stress}

Diverse strategies were reported in solving water scarcity in agriculture as individual adaptation. Farmers during interview and group discussion mentioned about the changing growing period of crops was one of the most practiced measures. Few farmers practiced drought resistant crop varieties and were strongly satisfied with it. Farmers were aware of System of Rice Intensification (SRI) and mentioned that it is highly effective under water stress condition although only few farmers were practicing SRI. Farmers during the group discussions suggested some options such as water pumping, agricultural water harvesting techniques that could be applied as an adaptation strategy to water scarcity in agriculture. However, majority of farmers are less aware of the adaptation practices among farmers. Lower rainfall is likely to have devastating effects in drier areas with rain-fed agriculture (MoNREC, 2016). Even water pumping and ground water availability will face challenges. Motivating farmers for adopting short-duration and drought-tolerant varieties would help to minimize the risk of crop failure from water stress (Arunrat at al., 2017).

Farmers were asked about their level of satisfaction on adaptation measures to cope with changing climate in agricultural yield, water stress/drought and soil degradation as shown in table 2 . Increasing the amount of fertilizer is the first priority for the farmers as a coping strategy followed by change in growing period. However, farmers have realized that increased chemical fertilizer application is not the best option. They were doing this due to barriers in adopting other adaptive measures. 
Table 2. Farmers's satisfaction with adaptation measures with regard to agricultural yield, water stress/drought and soil and land degradation

\begin{tabular}{|c|c|c|c|c|c|c|c|c|}
\hline Measures/Satisfaction & $1^{\text {st }}$ & $2^{\text {nd }}$ & $3^{\text {rd }}$ & $4^{\text {th }}$ & $5^{\text {th }}$ & Total & WAI & Priority \\
\hline \multicolumn{9}{|l|}{ Kampong Speu Province in Combodia } \\
\hline Increase amount of fertilizer & 3 & 9 & & 3 & 2 & 17 & 0.166 & 1 \\
\hline Change in growing period & & & & 16 & & & 0.09 & 2 \\
\hline SRI & 3 & 3 & & & & & 0.076 & 3 \\
\hline Water Pumping & & 3 & 3 & 2 & & & 0.07 & 4 \\
\hline Change in crop varieties & 3 & 1 & & & & & 0.054 & 5 \\
\hline Pond, dike and dam construction & 1 & & & & & & 0.014 & 6 \\
\hline Vegetable plantation & 1 & & & & & & 0.014 & 6 \\
\hline \multicolumn{9}{|c|}{ Kyaukpadaung township of Central Dry Zone region in Myanmar } \\
\hline Chemical fertilizer application & 0 & 26 & 9 & 0 & & 35 & 0.238 & 1 \\
\hline Foliar fertilizer application & 0 & 3 & 23 & 2 & & 28 & 0.155 & 2 \\
\hline Well land preparation & 1 & 11 & 4 & 1 & & 17 & 0.115 & 3 \\
\hline Animal manure application & 1 & 6 & 1 & 0 & & 8 & 0.058 & 4 \\
\hline Changing to high yield variety & 0 & 8 & 0 & 0 & & 8 & 0.058 & 4 \\
\hline Growing pure variety & 0 & 4 & 0 & 0 & & 4 & 0.029 & 5 \\
\hline Pursuing good crop management practices & 0 & 3 & 0 & 0 & & 3 & 0.022 & 6 \\
\hline Increased fertilizer application & 0 & 0 & 2 & 0 & & 2 & 0.011 & 7 \\
\hline Pursuing Crop rotation & 0 & 1 & 0 & 0 & & 1 & 0.007 & 8 \\
\hline
\end{tabular}

\subsubsection{Adaptation to Declining Soil Productivity}

According to farmers, they have adopted strategies for improving soil productivity. Those strategies include animal manure application; compost making and application; crop rotation and returning crop residues back to land for improving soil productivity. In particular, Dry Zone farmers prefer to apply animal manure rather than other practices because of its vast benefits, such as buffering capacity, effectiveness for plant growth and cheaper price. While farmers also reported of using chemical fertilizers for quicker benefits in terms of plant growth and yield regardless of its high cost. Similar trend of soil fertility management by farmers were reported in other study conducted in Cambodia that the farmers were well aware of soil fertility management (Touch et al., 2016a). The crop residue retention in their farmlands increased yield as well as this could reduce probability of crop failure during the period of higher temperature and rainfall variability (Montgomery et al., 2015). Recent research in Cambodian rain-fed lowland (Poulton et al., 2015) and upland (Touch et al., 2015) cropping systems has shown significant climate risk reduction by adjusting planting dates according to availability of soil moisture and better management of crop residues.

\subsection{Cooperative Adaptation to Climate Change Impact}

Cooperative actions are needed when an individual could not afford adaptation strategies. The best example of cooperative adaptation was for weeding. By forming groups, hand weeding was cooperatively carried out in agricultural fields of group members on the rotational basis. In fact, hand weeding by group of farmers was very beneficial for Dry Zone farmers not only to weed control but also to save money for wage labor for weeding. Farmer from Trapang Andong village also increased such cooperative actions. Several farmers already started practicing SRI in-group that has been introduced and some other farmers are also willing to adopt the same to cope with current climate. However, farmers emphasized on the barriers to adaptation strategies either adopted individually or through cooperative as described in table 3. 
Table 3. Adaptation strategies and limitation

\begin{tabular}{|c|c|c|}
\hline Problem & Strategy & Barriers \\
\hline \multirow{3}{*}{ Water stress } & Growing drought resistant plant variety & Lack of locally adapted variety \\
\hline & SRI & Lack of proper knowledge on SRI \\
\hline & Water pumping & Limited financial resource \\
\hline \multirow[t]{2}{*}{ Soil productivity declination } & Compost making and application & High labour demand \\
\hline & Fallow the cultivated land for 2 or 3 years & $\begin{array}{l}\text { Lack of compensation for } \\
\text { alternative livelihood strategy }\end{array}$ \\
\hline \multirow[t]{2}{*}{ Weed problem } & Herbicide application & High cost \\
\hline & & Lack of proper knowledge \\
\hline \multirow[t]{2}{*}{ Pest problem } & Fumigation by burning crop residues & Laborious and less effective \\
\hline & Digging small canal around the field to control rodents & Laborious and less effective \\
\hline
\end{tabular}

\subsection{Interactions among Institution, Technology and Farmers' Decision Making for Climate Change Adaptation}

In order to support climate adaptation and improve food security, we need to improve our understanding of the interactions among institution, technology and farmer decision making for climate change adaptation. Intervention from government becomes important when individual adaptation is not effective enough to cope with the impacts of climate change. National Commission for Environmental Affair (NCEA) of Myanmar is currently working to strengthen community resilience under climate change including activities, such as adaptive capacity building, awareness campaigns, training and climate change workshops throughout the country. In addition, establishment of NAPA (National action plan for adaptation) is ongoing under the enforcement. In addition, the government has implemented many mini and mega dam projects across the country in order to extend agricultural production. Currently, there are 140 dams constructed in the Dry Zone with watershed areas of 4.5 million hectares. Moreover, pumping water from the river is another attempt of government to cope with water scarcity in agriculture. However there is no proper policy for land as well as water use rights and government enforced to use water only for irrigation for rice cultivation. In Kampong Speu province, during the survey, $38 \%$ of farmers reported that the government and NGOs have disseminated adaptation technologies to reduce climate change impact on agriculture. Focus group discussions and key informants interview provided other technological intervention from government as well as NGOs, such as new rice varieties, providing water pumping machine during drought, road construction, SRI training and demonstrations, promoting vegetable seeds, fertilizers, rice storage techniques, and underground water pumping machine. Department of Agriculture in cooperation with Food and Agriculture Organization and with Live with Dignity organization were working on the climate change adaptation in agriculture in the two villages in Kampong Speu Province.

There is poor dissemination of research outcomes for the benefit of farmers due to poor linkages among government organizations, farmers, academic institutions and poor agricultural extension strategies according to the key informants. In Myanmar, there is no weather forecasting channel particularly for agriculture till date. Some farmers during the group discussions reported the need of such weather forecasting and communication system for early preparedness. Few local NGOs, Tun Lwin Foundation and Eco Dev, are trying to establish the networks to disseminate agriculture concerned weather forecasting. Studies showed that lack of information about the impacts of climate change and limited knowledge about adaptation measures being given as main reasons for not using any adaptation strategies (Arunrat et al., 2017). The study by Raut et al. (2012) indicated the success of agricultural extension through radio and television as a way of reaching farmers in which most of the farmers listened to or watch agricultural programs related to pest and diseases, use of organic and chemical fertilizers that were delivered via radio and television.

The agro-chemical companies are extending to sell out their products like pesticides and chemical fertilizers by pursuing different marketing strategies. However, their main mission is only to make profits without paying much attention on capacity building of rural farmers. Farmers were relying on those companies who provided extension staffs with agro-chemicals to be distributed to the farmers and farmers acknowledged the contribution of such extension services. In other study by Raut et al. $(2011,2012)$ in the region reported the efficient services on agro-inputs, agricultural exposure and trainings, provided by the NGOs compared to services provided by Government Organizations (GOs).

The agriculture adaptation to climate change therefore, should be addressed with a three-tier approach: 1) Institutional involvement and its extension must be strengthened and effective, 2) Region specific appropriate adaptation technology must be ensured, 3) Encouraging farmers for making decisions on adoption of adaptive 
strategies to climate change in agriculture through incentives. Agricultural extension services provide a mechanism for informing farmers about new technological developments. Based on the reflections by farmers who have already adapted and the successful stories in and around the similar geographical areas, the most appropriate adaptation technology should be ensured. The incentives to change ongoing cultivation practices with climate adaptive could be the driver of agricultural adaptation to climate change. This implies that for successful implementation of adaptation measures, the involvement of institutions and their extension should be strengthened and effective for region specific appropriate adaptation technology implementation.

\section{Conclusion}

Farmers in Cambodia and Myanmar use diverse adaptation strategies at household level to minimize the risk of climate change impacts on farming systems. They have changed cultivation practices with adaptive measures mainly for crop varieties, agricultural yield, water stress due to drought, and soil and land degradation. The adaptation strategies in both the countries include changes in crops grown, cropping calendar, machinery for cultivation practice, change in area for cultivation, system of rice intensification (SRI), water pumping, animal manure application, compost making and application, crop rotation and crop residues retention. Cooperative adaptation strategy was becoming successful among the farming communities when an individual could not afford adaptive measures. However, barriers to adaptation strategies are to be removed to promote climate adaptive practices in agriculture.

\section{References}

Adger, W. N., Huq, S., Brown, K., Conway, D., \& Hulme, M. (2003). Adaptation to climate change in the developing world. Progress in Development Studies, 3(3). https://doi.org/10.1191/1464993403ps060oa

Agrawal, A., \& Perrin, N. (2008). Climate adaptation, local institutions, and rural livelihoods. IFRI Working Paper W081-6. Ann Arbor, Michigan: International Forestry Resources and Institutions Program and University of Michigan.

Alauddin, M., \& Sarker, M. A. R. (2014). Climate change and farm-level adaptation decisions and strategies in drought-prone and groundwater-depleted areas of Bangladesh: an empirical investigation. Ecological Economics, 106, 204-213. https://doi.org/10.1016/j.ecolecon.2014.07.025

Arunrat, N., Wang, C., Pumijumnong, N., Sereenonchai, S., \& Cai, W. (2017). Farmer's intention and decision to adapt to climate change: A case study in the Yom anf Nan basins, Phichit province of Thailand. Journal of Cleaner Production, 143, 672-685. https://doi.org/10.1016/j.jclepro.2016.12.058

Ayers, J. (2011). Resolving the adaptation paradox: Exploring the potential for deliberative adaptation policy-making in Bangladesh. Global Environmental Politics, 11(1), 62-88. https://doi.org/10.1162/GLEP_a_00043

Bank, A. D. (2011). Asian development bank \& Myanmar[Fact Sheet]. Myanmar.

Bryan, E., \& Behrman, J. (2013). Community-based adaptation to climate change: A Theoretical Framework, Overview of Key Issues and Discussion of Gender Differentiated Priorities and Participation. International Food Policy Research Institute, CAPRi Working Paper No. 109. Washington, D.C.: International Food Policy Research Institute.

Bryant, R. C., Smit, B., Brklacich, M., Johnston, R. T., Smithers, J., Chiotti, Q., \& Singh, B. (2000). Adaptation in Canadian agriculture to climatic variability and change. Climatic Change, 45, 181-201. https://doi.org/10.1023/A:1005653320241

Dahal, B. M., Nyborg, I., Sitaula, B. K., \& Bajracharya, R. (2009). Agricultural intensification: food insecurity to income security in a mid-hill watershed of Nepal. International Journal of Agricultural Sustainability, 7(4), 249-260. https://doi.org/10.3763/ijas.2009.0436

Debela, N., Mohammed, C., Bridle, K., Corkrey, R., \& McNeil, D. (2015). Perception of climate change and its impact by smallholders in pastoral/agropastoral systems of Borana, South Ethiopia. SpringerPlus, 4(1), 1-12. https://doi.org/10.1186/s40064-015-1012-9

Department, A. P. (2010). Myanmar agriculture in brief. Naypyitaw: Union of Myanmar: Ministry of Agriculture and Irrigation (MOAI).

Devkota, R. P., Cockfield, G., \& Maraseni, T. N. (2014). Perceived community-based flood adaptation strategies under climate change in Nepal. International Journal of Global Warming, 6, 113-124.

https://doi.org/10.1504/IJGW.2014.058758 
DMO \& FD. Hazard profile of Myanmar. (2009). Yangon, Union of Myanmar: Department of Metrological Organization, Forest department \& Relief and Resettlement Department, Irrigation department \& fire Services Department.

Ellis, F. (1989). Peasant Economics, Farm Household and Agrarian Development, Cambridge University Press, Cambridge.

FAO, 2018, Myanmar at glance, http://www.fao.org/myanmar/fao-in-myanmar/myanmar/en/, accessed on January 15, 2018.

Habiba, U., Shaw, R., \& Takeuchi, Y. (2012). Farmer's perception and adaptation practices to cope with drought: perspectives from Northwestern Bangladesh. International Journal of Disaster Risk Reduction, 1, 72-84. https://doi.org/10.1016/j.ijdrr.2012.05.004

Heltberg, R., Siegel, P. B., \& Jorgensen, S. L. (2009). Addressing human vulnerability to climate change: Toward a 'no-regrets' approach. Global Environmental Change, 19(1), 88-99. https://doi.org/10.1016/j.gloenvcha.2008.11.003

Hinkel, J. (2011). Indicators of vulnerability and adaptive capacity: towards a clarification of the science-policy interface. Global Environmental Change, 21, 198-208. https://doi.org/10.1016/j.gloenvcha.2010.08.002

IPCC. (2012). Managing the risks of extreme events and disasters to advance climate change adaption. New York: Cambridge University Press.

IPCC. Climate Change (2007). Working Group II: Impacts, Adaptation and Vulnerability.

Jalilian, H., Reyes, G., \& Pide, L. A. (2010). Double Blow to the Poor: Cambodia's Food Security in the Face of the Food and Economic Shocks. In Annual Development Review 2009-2010. CDRI: Phnom Penh.

Kotera, A., Nguyen, K. D., Sakamoto, T., Lizumi, T., \& Yokozawa, M. A. (2014). Modelling approach for assessing rice-cropping cycle affected by flooding, salinity intrusion, and monsoon rains in the Mekong Delta, Vietnam. Paddy and Water Environment, 12(3), 343-354. https://doi.org/10.1007/s10333-013-0386-y

Le Dang, H., Li, E., Bruwer, J., \& Nuberg, I. (2014). Farmers' perceptions of climate variability and barriers to adaptation: lessons learned from an exploratory study in Vietnam. Mitigation and Adaptation Strategies for Global Change, 19(5), 531-548. https://doi.org/10.1007/s11027-013-9452-4

Lwin, T. (2010). Climate change in Myanmar during the last five decades. Yangon, Myanmar.

McSweeney, C., New, M., \& Lizcano, G. (2012). UNDP Climate Change Country Profiles: Cambodia.

MEF. (2010). Review of Cambodia Economy and Finance. Phnom Penh: Ministry of Economy and Finance. Cambodia.

MoNREC. (2016). Myanmar climate change strategy and action plan, Ministry of Natural Resources and Environmental Conservation, the Republic of the Union of Myanmar, Nay Pyi Taw, Myanmar.

Montgomery, S., Tighe, M., Guppy, C., Wright, G., Phan, S., Im, S., \& Martin, R. (2015). The effect of maize stover mulch on maize and sunflower yields in a no till farming system in North West Cambodia. In: Tropical Agriculture Conference. Australia, Brisbane.

NCEA. (2010a). Myanmar's initial national communication Report Draft copy. Yangon, Myanmar.

NCEA. (2010b). National report on the UNCCD implementation. Yangon, Myanmar.

Ndamani, F., \& Watanabe, T. (2015). Farmers'perceptions about adaptation practices to climate change and barriers to adaptation: A micro-level study in Ghana. Water, 4593-4604. https://doi.org/10.3390/w7094593

Paudel, B., Acharya, B. S., Ghimire, R., Dahal, K. R., \& Bista, P. (2014). Adapting agriculture to climate change and variability in Chitwan: Long-term trends and farmers' perceptions. Agricultural Research, 3(2), 165-174. https://doi.org/10.1007/s40003-014-0103-0

Poulton, P. L., Dalgliesh, N. P., Vang, S., Veasna, T., \& Charlesworth, P. (2015). Resilience of smallholder farmers in Cambodian lowland rice ecosystems in managing for future climate uncertainty. In Proceedings of the 17th Australian Society of Agronomy conference: Building productive, diverse and sustainable landscapes 20-24 September 2015, Wrest Point, Hobart, Australia.

Raut, N., \& Sitaula, B. K. (2012). Assessment of fertilizer policy, farmers' perceptions and implications for future agricultural development in Nepal. Sustainable Agriculture Research, 1(2), 188-200.

https://doi.org/10.5539/sar.v1n2p188 
Raut, N., Sitaula, B. K., Aune, J. B., \& Bajracharya, R. M. (2011). Evolution and future direction of intensified agriculture in the central mid-hills of Nepal. International Journal of Agricultural Sustainability, 9, 537-550. https://doi.org/10.1080/14735903.2011.609648

Sawano, S., Hasegawa, T., Goto, S., Konghakote, P., Polthanee, A., Ishigooka, Y., Kuwagata, T., \& Toritani, H. (2008). Modeling the dependence of the crop calendar for rain-fed rice on precipitation in Northeast Thailand. Paddy and Water Environment, 6(1), 83-90. https://doi.org/10.1007/s10333-007-0102-x

Smit, B., \& Skinner, M. W. (2002). Adaptations options in agriculture to climate change: a typology. Mitigation and Adaptation Strategies for Global Change, 7, 85-114. https://doi.org/10.1023/A:1015862228270

Swe, L. M. M., Shrestha, R. P., Ebbers, T., \& Jourdain, D. (2014). The farmers' perception and adaptation to climate change impacts in Dry Zone of Myanmar, Climate and Development, 7(5), 437-453.

Tiwari, K. R., Rayamajhi, S., Pokharel, R. K., \& Balla, M. K. (2014). Determinants of the climate change adaptation in rural farming in Nepal Himalaya. International Journal of Multidisciplinary and Current Research, 2, 234-240.

Tiyo, C. E., Orach-Meza, F., \& Edroma, E. L. (2015). Understanding small-scale farmers' perception and adaption strategies to climate change impacts: Evidence from two agro-ecological zones bordering national parks of Uganda. Journal of Agricultural Science, 7(10), 253. https://doi.org/10.5539/jas.v7n10p253

Touch, V., Martin, R. J., Scott, F., Cowie, A., \& Liu, D. L. (2016a). Climate change adaptation options in rainfed upland cropping systems in the wet tropics: A case study of smallholder farms in North-west Cambodia. Journal of Environmental Management, 182, 238-246. https://doi.org/10.1016/j.jenvman.2016.07.039

Touch, V., Martin, R. J., Scott, F., Cowie, A., \& Liu, D. L. (2016b). Climate change impacts on rainfed cropping production systems in the tropics and the case of smallholder farms in North-west Cambodia. Environment, Development and Sustainability, 1-17. https://doi.org/10.1007/s10668-016-9818-3

Touch, V., Martin, R., Liu, D. L., Cowie, A., Scott, F., Wright, G., \& Chauhan, Y. (2015). Simulation modelling of alternative strategies for climate change adaptation in rainfed cropping systems in NorthWestern Cambodia In Proceedings of the 17th Australian Society of Agronomy conference: Building productive, diverse and sustainable landscapes 20-24 September 2015, Wrest Point, Hobart, Australia.

UNDP \& MoE. (2001). Vulnerability and adaptation assessment to climate change in Cambodia. MoE; UNDP/GEF.

UNDP. (2011). Cambodia Human Development Report. Phnom Penh: UNDP.

UNFCCC. (2007). Climate Change: Impacts, Vulnerabilities and Adaptation in Developing Countries.

USAID. (2008). Kampong Speu Province Investment profile. USAID.

Vincent, K. (2007). Uncertainty in adaptive capacity and the importance of scale. Global Environmental Change, 17, 12-24. https://doi.org/10.1016/j.gloenvcha.2006.11.009

\section{Copyrights}

Copyright for this article is retained by the author(s), with first publication rights granted to the journal.

This is an open-access article distributed under the terms and conditions of the Creative Commons Attribution license (http://creativecommons.org/licenses/by/3.0/). 